\title{
Developing social and civic competence in secondary education through the implementation and evaluation of teaching units and educational environments
}

\author{
Concepcion Fuentes-Moreno (i) ${ }^{1 凶}$, Marta Sabariego-Puig (i) ${ }^{1} \&$ Alba Ambros-Pallarés (1) ${ }^{1}$
}

Recent international research in social science teaching highlights difficulties adolescents face when constructing social and citizenship awareness, and their own identity. To shed more light on this process, the present study is framed in the context of social science classrooms, and more specifically around how social and civic competence is developed via particular teaching methodologies and specific learning environments in Spain. The focus is on the analysis of democratic citizenship, as it is commonly accepted in the theoretical and epistemological bases of social sciences that citizenship education is one of the aims of the educational system. The objective of this study is to evaluate the effects of implementing two teaching units on the development of social and civic competence among 110 students in five secondary and high schools in Catalonia. A qualitative observational method is used to identify, describe and analyze the implementation and effects of both teaching units on a hermeneuticinterpretative basis. An ethnographic perspective is used to obtain accounts of education professionals and students. In addition, 19 field notes are analyzed using QSRNVIVO 12 software on two dimensions: citizenship and classroom climate. There are two main findings: first, regarding the formative value of both sequences regarding democratic, active and critical citizenship; the second, regarding the importance of the classroom environment created for this purpose by designing ad hoc learning spaces using active methodologies to contribute to the development of active and responsible citizenship. The conclusions highlight two important issues. The subject of History in secondary education should be vindicated as a key instrument to build democratic awareness, based on the skills of active and critical citizenship. Furthermore, there is a relationship between the development of critical and active citizenship and the creation of learning environments that foster reflection, analysis, interpretation and dialog. The implications of this study pose an important challenge for the study of social sciences. Initial teacher training methodology and syllabi should be reviewed, the importance of the Humanities in our society should be defended, and classrooms and schools should be democratized to promote active participation in citizenship education.

\footnotetext{
${ }^{1}$ Faculty of Education of the University of Barcelona, Barcelona, Catalonia, Spain. ${ }^{凶}$ email: conchafuentes@ub.edu
} 


\section{Introduction}

he relationship between Social Sciences teaching methodology and Citizenship Education has become much closer following growing interest from government institutions on the subject, given the new demands and challenges that must be faced in the training of future citizens.

Given this concern, this article is structured around how the social and civic competence is dealt with in Social Sciences classrooms in secondary education, and how it is contextualized in particular teaching methodologies and specific learning environments. To do this, we set out the theoretical and epistemological bases of Social Sciences teaching methodology that frame research in the analysis of democratic citizenship: these are critical and active.

The concept of citizenship itself is polysemic (Heimberg, 2010), confusing and difficult to specify in education, which has led to recent attempts to coin a more inclusive concept of citizenship that responds to the new demands and challenges of a changing society (Ramos, 2016). Thus, there develops an idea of citizenship that makes visible the plurality of identities, diversity and otherness as basic characteristics of democracy (Pagès and Santiesteban, 2010).

In the same way, when this idea is extrapolated to citizenship education, it is commonly accepted that the overall aim of the educational system is, in this regard, precisely to prepare for life and practicing democracy. López-Facal (2010) stated: "To train citizens in the broadest sense of the word-people who feel they are part of a world and society in which they can exercise their rights and have to assume their duties" (p. 5).

\section{Citizenship education in Spanish and Catalan curricula}

The relationship between citizenship education and Social Sciences teaching methodology is clearly demonstrated in the underlying concepts of social and civic competence that appear in school curricula.

On analyzing school history curricula in Spain, and particularly in Catalonia, one soon appreciates that the backbone of history education revolves around citizenship. History education is thus the main objective of the Social Science curriculum during compulsory schooling (Royal Decree, 2015; Decree, 2015). It is, therefore, essential that it be approached in a systematic and structured way. The basic competences of the social area of the Catalan curriculum (2015) are structured along dimensions, one of which is the citizen dimension which in turn, is made up of three area competences (1. to build critical and complex thinking skills to form an opinion based on facts and phenomena; 2 . to independently exercise rights and duties to live and participate in a social democratic society; and 3. to take a stance and engage in the defense of justice, freedom and equality among women and men). These competences emphasize the development of democratic, active and critical citizenship, and a commitment to the improvement of society and the environment, while always respecting human rights (Generalitat de Catalunya, 2015, p. 65).

Following content analysis of the citizen dimension in the Catalan curriculum, we found that the three competences converged around two skills, which, in turn, encompass the concept of democratic citizenship: critical citizenship and active citizenship (Leenders et al., 2008; Bolívar, 2016). These are defined below:

Critical citizenship implies having the skills to live and coexist in society and independently exercise the rights, duties and responsibilities of a democratic society, to engage in the defense and promotion of values such as cooperation, solidarity, commitment and participation. In this way, initiatives for planning, decision-making, organization and acceptance of responsibilities are promoted to gradually and sensibly assume the exercise of freedom, equity, and social and environmental justice (Generalitat de Catalunya, 2015, p. 70).

Active citizenship recommends educating students to responsibly exercise active citizenship through participation in community affairs. Community service can be considered as a curricular instrument that guarantees that students, throughout their schooling, experience and lead in acts of civic engagement, and put their knowledge and skills at the service of the community to learn to be citizens through the exercise of active citizenship (p. 71).

The active exercise of citizenship is essential to promote social skills and to appreciate the value of diversity, but is additionally important for the defense of common values in the face of all forms of discrimination (gender, age, beliefs, etc.) and intolerance (segregation, marginalization, exploitation, violence, etc.) (p. 74).

\section{The background to citizenship education and social sciences teaching methodology}

Despite the above guidelines and the undeniable value that learning about the historical dimension presents for the training of active and critical citizens, research in social science teaching has shown that adolescents have considerable difficulties in building their identities and their social and civic awareness (International Civic and Citizenship Education Study, 2016; Molina, 2016; Sáez et al., 2017a, 2017b). Furthermore, according to research by Delgado and Estepa (2017), despite identifying the importance of such difficulties, teachers display teaching practices that are far from objective. The explanations given are related to poor initial teacher training and continuing professional development, and conservative teaching methods used in classrooms (López-Facal et al., 2017).

Previous international research already outlines this trend. In Canada, an ambitious project was carried out entitled: Canadians and Their Past (Seixas et al., 2010). Based on analysis of the history education of a sample of the Canadian population regarding controversial topics in the public sphere and in schools, the authors establish a categorization based on understanding and analysis of the proposed topics. The most outstanding conclusions support the view that those with superior historical knowledge, have a greater capacity to critically question sources and provide more reasoned views when faced with controversial social debates. Thus, students who have a certain command of the scientific method of the field of history (understanding, analysis and interpretation of the context, data, etc.) are better able to approach interpretation of the past and the use of this past in analysis of the contemporary world.

Along the same lines, in the United States the topic has been approached by analyzing, among other aspects, the relationships between learning from the past and concepts of global citizenship (Myers, 2006), democratic education (Parker, 2003; Hauver, 2010), and memory of controversial topics (Yeager and Humphries, 2012).

Broadly speaking, the conclusions point to the great potential of including these concepts in Social Science classrooms to develop future citizens who are committed, fair and democratic (Delgado, 2014; Molina, 2016; Sáez et al., 2017a, 2017b). The authors insist that teaching practice, language, content and the organization of the classroom will determine the type of 
citizenship education that is taught and its long-term effects on the students.

In Europe the research picture is very similar. In France, the work of Tutiaux-Guillón $(2003,2009)$ focuses on the role of teachers as an element that fosters reflection and dialog in social science classrooms to create active and committed citizens. The problem noted in the conclusions is that teaching practices (teaching methodology) do not favor the development of democratic attitudes and highlight a divorce between the desire to train citizens and teachers' own teaching practice (Tutiaux-Guillón, 2003).

Along these lines, the United Kingdom (Trafford, 2008), Italy (Mattozi, 2008) and Brusa, 2010), Switzerland (Heimberg, 2010), and Belgium (Rey and Staszweski, 2004), coincide when pointing out the progress made in the field of citizen training at a theoretical level, either in the form of specific subject design or crossdisciplinary themes in competence curricula. For such training, there is also the undeniable value given to the social sciences and, more specifically, to history (Mattozi, 2008), the content of this discipline being an excellent framework to train young people as future active, responsible and democratic citizens.

Despite this, the context and the internal functioning of centers require modification to become democratic centers in which the rights and duties of all members are recognized. Research coincides by pointing out that students must develop their capacity to be free and responsible citizens through activities in which they apply their learning and exercise citizenship in a school environment, allowing them to connect with the knowledge acquired in social science classrooms (Heimberg, 2010).

Another line of research that converges with the previous results is that related to citizenship education: the construction of national, individual and collective identities. Work from Portugal by Barca, and also from Brazil, by Schmidt, is pivotal. They start from the analysis of historical narratives and how these identities are constructed. The conclusions note the importance of the teaching of history, both as regards research methodology and content, since it makes a contribution in helping students define the processes of change, thereby reconsidering the concept of citizenship and identity (Barca and Schmidt, 2013).

At the same time, work in Portugal stands out in linking the construction of historical awareness and citizen awareness, and the construction of identity and heritage, pointing out how work on historical sources can help to understand the past, establish inferences and to become critically aware, aspects that contribute to developing social and civic competence (Pinto, 2013; Santacana and Martínez, 2013).

The relationship between citizenship education (social and civic competence) and the teaching and learning of history in Spain follow the line of previous work at an international level. Various studies coincide in noting the potential of history as a subject in dealing with social and civic competence with its students, introducing innovations such as dealing with relevant social problems, using interactive learning methods and the capacity for reflection and criticism. In this way, the stereotypes and prejudices that negatively condition significant learning can be reduced in a sustainable way (Pagès and Oller, 2005; Pagès and Santiesteban, 2010; Valls, 2009; Prats et al., 2017; Molina et al., 2013), and can engender democratic citizenship.

The Alpha II Project entitled "Teaching of History and Collective Memory", coordinated by Carretero, points in exactly the same direction, incorporating reflections on the construction of collective memory and the fundamental influence that school history and textbooks have on it (Carretero, 2007; Carretero and Borrell, 2008; Bromley, 2009; Mejía, 2009).

López-Facal (2011) and Molina et al. (2013) carried out a study on the conceptions that students have of citizenship education, based on four fundamental needs: promoting social cohesion, ensuring political unity, creating a democratic collective identity and generating rights and liberties. Having analyzed these questions, they reach the conclusion that the social sciences play a critical role in creating a civic identity and the development of social and civic competence among students. In the authors' opinion, it is necessary to involve students in contexts or learning environments that generate participatory and committed attitudes, whether in the classroom, the school board or the immediate social environment, by surrounding the student with a "democratic space" in which to function (Delgado, 2005). It is essential to make a change in educational approach, rethinking the idea of democracy, not only as an assumption of norms, but incorporating active methodologies and selecting historical content (García-Pérez and de Alba, 2008).

Along the same lines, Armas and López-Facal (2012) relate three key elements to dealing with social and citizenship competences in social science classrooms: historical awareness, construction of identities and dealing with conflictive issues. They conclude by warning of the need to deal with conflicting historical issues in class by generating teaching methodologies that promote democratic classroom management through debate.

\section{Research background}

This article takes into account previous research relating to two issues. The first is that schoolchildren present highly discernible difficulties when it comes to building their social and civic dimensions, and usually use dominant social stereotypes. With proper initial teacher training and continuing professional development, as well as implementing inquiry-based methodology and materials that foster participatory and critical attitudes in the classrooms themselves, this trend could be reversed (Schulz et al., 2018; Prats et al., 2019; Fuentes et al., 2019).

The second relates to the influence of learning environments and the teaching of social and civic competence. Research reveals that it is essential for teacher trainees to have control over the planning, design and development of learning spaces (Duarte, 2003; Antúnez, 2013; Castañeda, 2019) to understand the learning of this competence in a more systemic way. The notion of educational environments responds to a diverse and complex notion related to the set of elements and subjects-actors who participate in a teaching and learning process. In a learning environment, the challenge is to integrate the whole set of elements (activities, classroom climate, relationship among the participants, etc.) and systematically relate them effectively and efficiently to achieve the intended objectives.

Another aspect to take into account in teaching environments is the role played by the setting in which activities occur, with the creation of favorable conditions, that is to say, a time and space in constant movement in which participants develop skills, competences, abilities and values. The environment integrates the dynamics that constitute educational processes, and which involve the actions, experiences and life lessons of its participants.

In this way, if the intention is to educate in social and civic competence in social science classrooms, spaces for citizen participation should be identified where the student can be personally involved in discussion, decision-making, generating spaces of discrepancy and dialog (Ramos, 2016). It should be noted that it is not the spaces themselves that delimit learning, but the way in which educational action is proposed within them (Gil-Jaurena, 2012; Sánchez-Melero et al., 2016).

As noted, the starting point is the fundamental role of the teacher in promoting appropriate and essential learning environments for the construction of knowledge and attitudes. The success of citizenship education in social science classrooms 
should not reside so much in the content, undoubtedly important, but in the ability of the teacher to be able to promote more active approaches based on analysis of social problems and participation in the classroom, the center and in social life (Bolívar, 2007).

In this context, there is a clear need to come up with a new methodological paradigm in the initial training of future teachers (Sánchez-Agustí, 2011; Imbernón, 2007). Such a paradigm seeks more open, changeable, critical and compelling visions of the educational act and related to the classroom climate created.

Future history teachers face such challenges in addition to having to contend with stereotypes that have confined their subject to explanatory and rote learning approaches, presenting them as closed and complete areas of knowledge, devoid of meaning and interest for a large number of students. Studies of social science teaching concur in highlighting the considerable educational value that history offers. Whether classroom work involves inquiry or discovery, it generates the use of primary cognitive skills in students, such as classifying, analyzing, reflecting, and inferring.

School history should not be conceived of as a body of complete knowledge, but as an approach to a body of knowledge under construction. Recommendations resulting from research indicate a path to a subject focused on the formulation of questions about the present and the past, deducing causes and consequences, questioning situations or explanations about facts, proposing hypotheses, detecting prejudices, making rational and informed explanations of the facts and phenomena of the past, and extrapolating from historical situations, among others (Prats and Santacana, 2011).

\section{Research context}

These assumptions led a research group to generate resources and materials to work on social and civic competence in classrooms using active and participatory methodologies framed in collaborative learning contexts, and calibrate their effect on students. At the same time, it aimed to provide both trainee and active trained teachers with instruments that allow them to reflect on practice and generate changes in educational contexts that allow the development of democratic, responsible and participatory citizenship.

Thus, the study focused on the design and implementation of five teaching units with different topics: "Women and the Industrial Revolution"; "The loves of my life"; "Athens, the origin of democracy"; "Democracies and totalitarianism" and "The Maze: Us and them". The common denominator among these sets of materials is that they contain systematic work on social and civic education concerning aspects related to the construction of one's own criteria regarding major social problems. These include the promotion of active participation to exercise rights, duties and responsibilities in a democratic society, and defense of the concepts of justice, freedom and equality. These key concepts should be constructed through the use of discovery-based teaching methodologies based on a challenge or question approach, analysis of sources, and the application of historians' hypothetical-deductive method. In this context, the teacher's role, apart from being essential to fulfill teaching aims and specific competences, is to be a guide in the process, while students are expected to generate real participatory attitudes to proposed conflicts, building their actions and their learning in a consensual way.

\section{Teaching materials for the study}

This paper specifically analyses the implementation of two sets of teaching materials that converge in a particular way in the development of citizenship education. These sets are named "Athens, the origin of democracy" and "The Maze: Us and them" (henceforth "Athens" and "The Maze"). Below, we outline their principal features as in teaching terms, they share the same fundamental characteristics mentioned above.

The "Athens" teaching unit is designed to be implemented in the first-year of secondary school. Different types of citizen social participation are covered on a journey from Athenian democracy to our current representative system. The unit places special emphasis on cross-curricular treatment of the concept of citizenship and political participation. Using a hypothetico-deductive method, we pursue the following objectives: (1) to identify the various ways in which people can participate in decision-making; (2) to draw distinctions between dictatorship, direct democracy and representative democracy; (3) to compare some aspects relating to the functioning of the Athenian political system and that of the current Spanish model, with particular regard to citizen participation; (4) to read, analyze and interpret different kinds of historical sources. With regard to the Catalan curriculum (2015), the materials cover the historical, geographical and, above all, citizenship and area-related competences. In addition, there is also a short dramatization in which students become Greek citizens and have to make decisions on various issues.

"The Maze" is applied in three schools and the content is worked on in three different subjects: Social Sciences, Culture and Values, in the fourth-year of secondary, and Philosophy, in the first-year of high-school. Students embark on a journey via three different moments in the history of mankind, including a futuristic scenario (the Roman Empire, the Germany of the Third Reich, and imaginary futures in science fiction literature in the form of dystopian societies, which permit analysis of the present from a convenient distance). The fundamental aim is for pupils to work on identity and difference aimed at the social and citizenship competence through gamification activities. The starting point is the design of a role-playing game with the Classcraft Learning Managment System as an online platform to deliver content (Hurtado et al., 2019). The unit is therefore not limited to printed material, but delivered using a variety of computer and audiovisual means. This approach fosters the development of the historical and citizenship dimensions of the Catalan ESO (compulsory secondary education) curriculum (2015).

\section{Methods}

Objectives. The general aim of the research is to evaluate the effects of the implementation of two teaching units ("Athens" and "The Maze") on the development of social and civic competence in 110 students from five secondary and high schools in Catalonia who study Social Sciences, Culture and Values, and Philosophy.

The specific aims of the article are the following:

a. to provide evidence of the formative capacity of the teaching units in the development of social and civic competence in secondary school students, with a particular emphasis on the degree of acquisition of critical citizenship and active citizenship by students through their implementation in the classroom.

b. to identify the characteristic elements of educational environments (Duarte, 2003) created ad hoc to contextualize the development of the aforementioned teaching units in each particular context.

Research design and data collection instrument. An observational method (Bartolomé, 1984; Anguera, 1988; Travers, 1971; Van Dalen and Meyer, 1980) was used to identify, describe and analyze the implementation and effects of both teaching units in 
the classroom, using experiences, designed learning processes and contexts (Alves, 2002; Oliveira and Alves, 2002; Chaluh, 2012). This aim justifies the hermeneutic-interpretive foundation to describe and interpret this experience in real settings (Maykut and Morehouse, 1999; Wood and Smith, 2018), and the ethnographic perspective (Sabariego, 2010) to obtain the account of education professionals and the students themselves concerning the elements that favor the development of critical and active citizenship among the parties involved.

This observational process involved conducting fieldwork between January and June 2018, which was structured in three stages (Prats et al., 2019):

First: the running of four initial training sessions for observers on the observation modality, selection and access to the scenarios. The main interest was to ensure agreement between observers for greater objectivity and precision of the records obtained, as well as to meet the minimum requirements of reliability (objectivity) in the study.

Second: the definitive design of the observation guide and the field notes recording template with the general questions and dimensions to guide the collection of information related to the objectives and theoretical framework of the study. The fieldwork was carried out through a non-participant, direct and open observation modality, with an average duration of one hour per session. Descriptive-narrative records (field notes and memoranda) were chosen, often supplemented with the use of auxiliary means to obtain audio recordings and photographs, with the prior informed consent of the students' legal guardians. Ethical issues and questions regarding the protection of personal data in these situations were approved by the Ethics Committee of the University of Barcelona.

The observational record advanced via selective logic (Spradley, 1980) in each session, initially descriptive and gradually more focused as the activity progressed to focus on its more specific dimensions regarding the educational value of resources and the pupils' competence development: the contents dealt with, the development of social competences (through the narrative and argumentative competence expressed in school narratives and speeches), the attitudes of pupils, the experiences and experiences in the classroom, the role of the teacher and the material and socio-affective conditions of the climate in the contexts studied. The records were transcribed to ensure the confidentiality and anonymity of the participants.

Third: the development of group work sessions parallel to the observations in order to share impressions, coordinate classification of the data and discuss characteristics of the observation, saturation of information and categories of emerging analysis. Data analysis began at the moment of data collection and consisted of a continuous review of the material obtained, to redirect and guide the information collected in the same observational process of each context, considering the most relevant content categories that were emerging.

Participating centers and contexts. This article draws on a previous research process ${ }^{1}$ and focuses on the evaluation of two teaching units applied in five class groups of four Secondary Education schools (third and fourth years) of the Autonomous Community of Catalonia. The teaching units were specifically implemented in the context of the subjects of Geography and History, Social Sciences, Culture and Values, and Philosophy taught by teachers interested in the content of the curriculum of

\section{Table 1 Teaching units by educational centers.}

\begin{tabular}{|c|c|c|}
\hline Teaching units & $\begin{array}{l}\text { "Athens, the origin of } \\
\text { democracy" }\end{array}$ & $\begin{array}{l}\text { "The Maze: Us } \\
\text { and them" }\end{array}$ \\
\hline \multicolumn{3}{|l|}{ Centers } \\
\hline Center 1 & & 4 \\
\hline \multicolumn{3}{|l|}{ Center 2} \\
\hline Center 3 & 2 & \\
\hline Center 4 & & 4 \\
\hline Center 5 & 6 & 3 \\
\hline Total & 8 & 11 \\
\hline \multicolumn{3}{|c|}{$\begin{array}{l}\text { Number of sessions and records obtained. } \\
\text { It shows the information obtained from five schools regarding the records of the sessions, which } \\
\text { are systematized in the two columns of Table } 1 \text { (see shaded area). They correspond to two first- } \\
\text { year ESO (secondary) groups during the implementation of the "Athens" teaching unit, one } \\
\text { third-year and one fourth-year ESO group, and a first-year high-school group in the case of "The } \\
\text { Maze". } \\
\text { From: own elaboration based on data. }\end{array}$} \\
\hline
\end{tabular}

these subjects with regard to the development of social and civic competence.

In the study, we opted for subjective sampling in selecting eight participating schools according to explicit pragmatic criteria, such as manifest interest in the teaching units, and the feasibility and accessibility of the contacts. Table 1 summarizes the distribution of teaching units ("Athens" and "The Maze") in all participating educational centers, records from which were also included.

In total, 19 field notes records recorded by 5 researchers concerning 5 teachers were obtained. In addition, the researchers performed a parallel analysis by completing a memorandum. In all, eight records on the implementation of "Athens" and eleven for "The Maze" were analyzed, which were implemented with an overall sample of 110 students.

"Athens": to two first-year ESO (secondary) groups during the implementation of the "Athens" teaching unit in the social sciences subjects of Geography and History.

"The Maze": one third-year and one fourth-year ESO (secondary) group who study Social Sciences, and Culture and Values, and a first-year high-school group in Philosophy.

Analysis of the information. Analysis was carried out using the QSRNVIVO $12^{2}$ software program to speed up activities such as segmentation of the text into quotations, coding or writing of comments (Gibbs, 2012). After literal transcription of the observation records, we proceeded to qualitative analysis, at three progressive levels of reduction and theoretical structuring of information:

Level 1: Reading and preceding. We proceeded to read the transcripts of the observational records to identify the first units of meaning and encode the text into initial and emerging categories.

Level 2: Construction of a definitive category system. From the previous level, the categories of analysis between observers were agreed. This procedure followed a dual process: deductive, generating the categories derived from the theoretical framework and previously published works (Molina, 2016; Fuentes and Prats, 2013; Prats et al., 2017); and inductive, considering the initial categorization from the memoranda and the level of analysis carried out during the fieldwork.

Having established an initial provisional system of categories and subcategories, the research team coded a small sample of texts individually. This was followed by group analysis that resulted in the restructuring and consensus of the following definitive category system to encode the record of all observations (see Table 2) from two central analysis units: the formative 


\section{Table 2 System of agreed categories for observation analysis.}

I. Contextualization: characteristics of the center and students (socio-economic and socio-cultural level, school context, and incidental information (pupils' ages, educational level, subject for which the educational materials are used).

II. Adequacy of space: favorable conditions for carrying out the activity (furniture arrangement, interaction between real and virtual space, technological support).

III. Assessment of teaching methodology: development and assessment of the teacher's work regarding the teaching unit (dynamics, use of resources, timing, sequencing of activities, adaptation of material to diversity, modification of material)

IV. Competence development of democratic citizenship:

1 Critical citizenship: evidence of skills, beliefs and values committed to the defense and promotion of cooperation, solidarity and the inclusion of diversity expressed in the classroom during the implementation of the teaching units.

2 Active citizenship: evidence of the exercise of citizenship via participation in issues that affect the community and civic engagement actions observed in the classroom during the implementation of the teaching units.

V. Student motivation: predisposition to carry out the activity (intrinsic interest, extrinsic utility, significance/meaning).

VI. Classroom climate: adequate learning environment (class cooperation, attitude, respect for norms, teacher and student roles).

Categories, subcategories and definition

Having established an initial provisional system of categories and subcategories, the research team coded a small sample of texts individually. This was followed by group analysis that resulted in the restructuring and consensus of the following definitive category system to encode the record of all observations from two central analysis units: the formative potential of the units implemented

(considering the context, the space, the methodology and the teaching role during its implementation), and students' competence development with regard to critical and active citizenship.

(considering the context, the space, the methodology and the
From: own elaboration based on group previous analysis.

potential of the units implemented (considering the context, the space, the methodology and the teaching role during its implementation), and students' competence development with regard to critical and active citizenship.

Level 3: Sequential analysis of information. Interpretation of the data in the light of the theoretical framework and the categories of analysis. We performed content analysis for indepth sequencing of the information. For each category, we analyzed the results from a dual perspective: (a) generally, to obtain an overview of the specified categories, and (b) by teaching unit profiles, to qualify the data in both types of validated resources, paying attention to both common points and divergences in the development of democratic citizenship in the implementation of "Athens" and "The Maze".

We present the results below, taking into account two basic dimensions of the analysis:

a. the formative capacity of the teaching units for the development of critical citizenship and active citizenship in the classroom, together with evidence of this competence development in students; and

b. the systematization of this information also allows us to point out some of the most relevant characteristics of the learning environments (Duarte, 2003) created ad hoc in each context, including fragments extracted from the observations that exemplify the findings.

\section{Results}

The training capacity of the teaching units for the development of active and critical citizenship. Both "Athens" and "The Maze" help secondary school students build democratic citizenship through the historical content, civic values, and civic and citizenship education that are worked on in the contexts under study. Table 3 shows this with the percentage of references in the categories analyzed to attitudes, values, and judgments regarding active citizenship and critical citizenship during observation of the implementation of the teaching units.

Taking into consideration the total of the observational records for "Athens", it is apparent that this teaching material allows for well-balanced development of both competences. Balanced percentages can be observed that show similar relevance or 'weight' of words coded for both categories when it comes to expressing skills, beliefs and the exercise of active and critical citizenship (52.94\% and $47.06 \%$, respectively). As regards the
Table 3 Comparative coding matrix.

\begin{tabular}{lll} 
& "Athens" & "The Maze" \\
\hline Active citizenship & $52.94 \%$ & $60.87 \%$ \\
Critical citizenship & $47.06 \%$ & $39.13 \%$ \\
Total & $100 \%$ & $100 \%$ \\
\hline $\begin{array}{l}\text { Percentage of references in the categories analyzed attitudes, values, and judgments regarding } \\
\text { "active citizenship" and "critical citizenship" during observation during the implementation of } \\
\text { the teaching units. } \\
\text { From: own elaboration based on data. }\end{array}$ \\
\hline
\end{tabular}

training value of "The Maze" material, it is slightly more effective in developing the exercise of active citizenship in students, taking into account these same indicators.

Both teaching units allowed for the creation of a critical and inclusive learning environment in the classroom, promoting attitudes in keeping with responsible democratic citizenship. Let us now turn our attention to some interesting nuances that have been identified for online competence development with regard to active citizenship and critical citizenship.

If we focus more specifically on the evidence linked to the development of active citizenship, during the implementation of the teaching units there are references to promoting the responsibility of adolescents towards social issues, especially to participatory and ethical values in the face of issues of a political nature and civic engagement. Both teaching units promote attitudes typical of responsible citizenship, but in line with the previous results, "Athens" clearly enhances their development, as illustrated by the following fragments of the records obtained ${ }^{3}$ :

So that they understand the ecclesia refers to the school board and they do consider it more democratic if all the representatives that make up the school communityparents, students, teachers, management teams, cleaning staff, janitors, etc. can participate, and what it would be like if only teachers sat on the school board. (A01_S03)

The proposed teaching materials enhance the analysis of social reality and the construction of structured historical knowledge, based on work on citizen social participation in Athenian democracy, covered in the Athens teaching unit. This proposal presents the student with situations and attitudes towards the defense of justice and equality, an aspect that is reported in reflections such as the following: 
Democracy means the ability of the people to make decisions and an increase in citizen participation in political issues. However, students point out that in classical Greece, women, children, slaves, metics... were not considered citizens and, therefore, could not participate in politics. (A01_S07)

A student of Asian origin expresses pleasure at the idea that the citizens of Athens could participate in politics, considering that it was something that the whole community expected, since it guarantees union between peoples. (A01_S09)

If we focus on the teaching methodology to promote the development of this competence, "Athens" encourages interactive learning methods, and reflective and critical skills in the students regarding the value of participation, fundamentally understood as a right (the right to vote) or as a real practice exercise in the face of all forms of discrimination (gender, origin, beliefs, etc.). This is evidenced by the literal comments in the observational records from its implementation in educational contexts:

Another girl intervenes, expressing her agreement with the decision, but calls for women to also have this right. (A01_S09)

Reviewing the previous class, the teacher asks the students who the citizens were. Their answer is: everyone who lived in Athens, without distinction according to class, religion, skin color or gender. (A05_S05)

In the classroom citizenship is exercised by motivating and simulating the role of students as citizens, creating learning contexts focusing on the question of historical content, and relating them to human rights, the treatment of relevant social problems and identification with other events, or more familiar or better known forms of discrimination (for example, totalitarianism, such as Nazism). The cloud mark ${ }^{4}$ in Fig. 1 allows for more detailed analysis of the most frequent words and their meaning in the context of observations when they refer to the development of active citizenship. Students express their views in the classroom in terms of questions that the teacher encourages them to answer on topics related to the contents dealt with in the classroom, from the historical dimension (slaves, women in Athens) and their identification with other social, cultural and civic groups (in this case, Nazism in Germany).

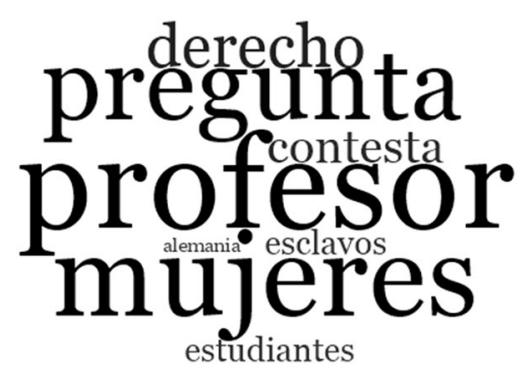

Fig. 1 General cloud mark with an account of the development of active citizenship in the educational contexts observed. This visualization called a cloud mark is the result of the word frequency query that Nvivo allows in this case of the "Active citizenship" node: it illustrates the terms or the words that are most often repeated in the references categorized under this node of all the records obtained and indicates-proportionally by sizetheir greater or lesser presence and relevance in the observations of both sets of teaching materials. The translation of the words from Spanish to English in descending order from highest to lowest is: teacher, women, question, law, answer, slaves, students, Germany. From: Nvivo data.
Another of the competences that "Maze" and "Athens" allow development of appears to be linked to the construction of critical and complex thinking, as well as positioning and committing to the defense of justice, freedom and equality, with an emphasis on development of critical citizenship.

Both units have urged students to reflect on all these aspects and create their own criteria on relevant social problems in coherence with the exercise of skills to live and coexist in society, autonomously exercising the rights, duties and responsibilities of a democratic society. The following literal comments are intended to demonstrate this effect of the implementation of "Maze" and "Athens" in the contexts analyzed:

The adolescents reflect on the concept of democracy. They consider that democracy is a much more suitable system than oligarchy, since democracy is government by the "demos", while oligarchy is only the privileged, and they do not take into account the needs of the poorest. (A01_S03)

During the classroom the students and the teacher refer to the context of the current crisis in the neighborhood where the center is located: Nou Barris (a deprived area in Barcelona). Students comment that the crisis always affects the poorest neighborhoods and the less fortunate and that this is unjust. (M01_S01)

On more detailed investigation into the work carried out from both teaching units for the exercise of critical citizenship, the analysis of observational records reveals two key aspects: the value given to the treatment of conflictive issues from a historical perspective (this is the case of minority groups such as women, especially, but also slaves and poor people in classical Athens); and critical analysis of social reality to advance the attitudes and skills underlying this competence in the classroom:

The students criticized the eugenicist view, considering it clearly racist (...). Some of them argue that this theory is deeply unfair and they totally disagree. They say that the education one receives can change this. (M01_S03)

Adolescents explain in this guided review that democracy is much better than oligarchy because, as the word indicates in democracy, the demos participates, in the oligarchy only some privileged and powerful people who do not take into account the needs of the poorest. (A01_S03)

Figure $2^{5}$ illustrates the terms or words most often repeated in the references categorized under "Critical citizenship" of all the records obtained from the observations of both sets of teaching materials. As can be seen, the word "people" emerges as the most relevant to refer to the dynamics proposed for the defense of common values and intolerance of segregation, marginalization, exploitation or violence. This is evidence of the awareness fostered by these teaching units in the face of relevant social problems, generating a culture of basic critical thinking when it comes to building citizenship and participatory awareness.

Learning environments for the development of civic competence. The second objective of this study is to obtain a global vision of the learning environments created ad hoc to contextualize the implementation of these teaching units, and the contexts studied for the development of social and civic competence.

A first reference to proceed in this analysis is offered by the following dendogram in Fig. 3 or cluster analysis ${ }^{6}$ via Nvivo software. This is a visualization that illustrates the level of similarity between the analysis categories used in this study, 


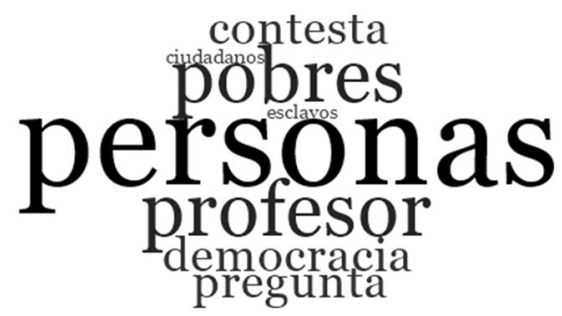

Fig. 2 General cloud mark with the account of the development of critical citizenship in the educational contexts observed. This visualization called a cloud mark is the result of the word frequency query that Nvivo allows in this case of the "Critical citizenship" node: it illustrates the terms or the words that are most often repeated in the references categorized under this node of all the records obtained and indicates-proportionally by sizetheir greater or lesser presence and relevance in the observations of both sets of teaching materials. The translation of the words from Spanish to English in descending order from highest to lowest is: people, poor, teacher, democracy, question, answer, citizens, slaves. From: via Nvivo data.

\section{Elementos conglomerados por similitud de palabra}

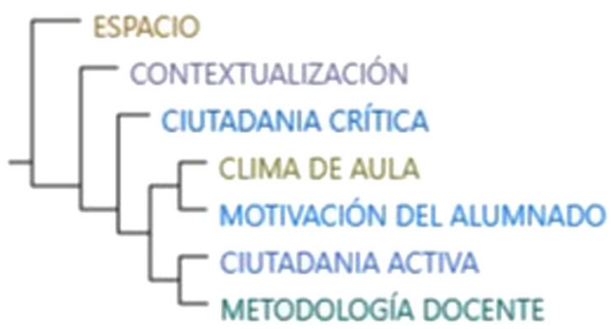

Fig. 3 Cluster analysis: conglomerated categories by word similarity. Cluster analysis is a visualization offered by Nvivo to illustrate the grouping or similarity of analysis categories used in this study according to the words or terms used in the references coded by each of them. The translation from Spanish to English starting with the word "Espacio", "Space" onwards are: contextualization, critical citizenship, classroom environment, student motivation, active citizenship, teaching methodology. From: via Nvivo data.

taking into consideration the words or terms that are used in the references coded by each of them: it shows that critical citizenship development is expressed in terms related to contextual description and accounts of classroom climate and student motivation. By contrast, the description of critical citizenship development shares a greater correspondence in content and word similarities with teaching methodology.

The learning context created in the classrooms involved maintaining an open environment for discussion and expression, with special emphasis on the use of methodologies that foster the ability to critically analyze information and the surroundings. There are thus many accounts that allude to the teacher's fundamental role when it comes to fostering the contrasting of sources and the detection of prejudices regarding the topics covered in the teaching units:

All students participate and answer the questions raised by their teacher (Elvira) about Athenian democracy, reconstructing the historical narrative. Despite their mistakes, students do not feel inhibited and continue to come up with historical interpretations, guided by their teacher. (A01_S03)

The teacher starts from an explanation of the concept of race according to National Geographic. The teacher backs the idea behind the video that there are no human races because there are no isolated populations. (M01_S03)

In the narrative analysis we observed that these mechanisms led to participatory and motivational attitudes and interest in student learning:

The teacher gives an explanation accompanied by very shocking images. For example, a photo opposing the sterilization of women in the US in the $60 \mathrm{~s}(\ldots)$. The children protest and do not understand these decisions. (M01_S03)

Both "Athens" and "The Maze" promote active teaching methodologies that makes the student the protagonist of their learning in constructing their own criteria towards relevant social problems. The main strategy to boost classroom energy focuses on questions and reflections arising from the teacher's presentation, and investigation or discovery-based work methodology, as illustrated by the following excerpts that allow us to contextualize experiences:

The teacher (...) asks students some interesting questions, such as if they think that the laws of genetics can explain economic, social, cultural or health success (...) Students reject this argument and seem annoyed. (M01_S03)

The teacher constantly uses a dialog approach to reconstruct a narrative on Greek democracy on the basis of class activities. Each source is accompanied by questions helping pupils derive information in order to answer. (A05_S05)

Of particular importance are the tools used to include historical content and visions of the past to identify and understand presentday societies, creating a degree of awareness of social problems.

The teacher takes a few minutes to remind students of the importance of sources in history. The teacher reminds them that in history there are three fundamental aspects to know about the past: where something happened, shown on a map, when, displayed on a chronological axis, and how it has reached us. (A01_S05)

The explanation resumes. The teacher uses a photo of soup kitchens in the United States during the Great Depression for comparison with the current situation in their neighborhood in relation to soup kitchens. (M01_S01)

The aim is to offer students the space to deduce causes and consequences; question situations or explanations regarding the facts; give rational and informed explanations of the facts and past phenomena, and extrapolate historical situations (Prats and Santacana, 2011). In this active logic approach, the use of dramatization in the Athens teaching unit also proved valuable: it presented students with the various forms of participation in Athenian democracy, allowing them to analyze forms of participation up to and including our current representative system. There is also a special emphasis on the cross-curricular treatment of the concept of citizenship and political participation from an experiential perspective, and of critical analysis of information and its context (Ramos, 2016).

The teacher reminds students that all this effort will result in a short dramatization in which students will have to act as Greek citizens and take decisions, so they have to learn how the whole system worked in order to do it well. (A01_S03)

Reviewing the previous class, the teacher asks the students who the citizens were. Their answer is: everyone who lived 
in Athens, without distinction according to class, religion, skin color or gender. (A05_S05)

A slave comments that she is not happy with the idea. Slaves born in Athens are more citizens than the foreigners. They are slaves only because they have lost everything, but they are Athenians. (A01_S07)

\section{Discussion}

Based on the results analyzed above, this study confirms the value of knowledge in the field of social sciences teaching methodology for the construction of active citizenship in educational processes (Edwards et al., 1994). Historical knowledge greatly articulates the development of social competences in compulsory education and in high-school, and therefore constitutes a coherent and significant curricular space when faced with the challenge of training citizens to be aware of their duties and rights, and to be active agents in a democratic society.

The study confirms the training potential of two teaching units, implemented in secondary educational contexts and within the framework of social science teaching, and its value for learning about active and critical citizenship. The justification for this impact is not only attributable to the content and format of both units, but above all to the educational use and context created for this purpose. A decision was made to modify the teaching of social sciences by designing ad hoc learning spaces, based on activities founded on specific methodological concepts for the identification and analysis of practices and experiences through which students can learn to be and act as citizens (Mata and Aguado, 2007; Gil-Jaurena et al., 2011; Mata and Ballesteros, 2011; Mata et al., 2012).

The development of active and critical citizenship, as presented in the dendrogram of Fig. 3, required active methodologies for its development and expansion: interactive learning methods, as well as the ability to reflect and critique information related to ethical, moral and citizen organization issues in an open and emotionally sensitive climate (Molina, 2016; Prats et al., 2017). This evidence coincides with the definition of citizenship as a concept that must be continually rebuilt and endowed with meaning and significance (Walzer, 1997). The dynamic and relational nature of the concept has also spurred the creation of learning contexts in which to recreate a collective form of active membership in the community (Benedicto and Morán, 2003) when faced with historical content (democracy in Classical Athens), and to relate these contexts to human rights, dealing with relevant social problems and identification with other more familiar or better known events or forms of discrimination (for example, totalitarianism such as Nazism) to advance the attitudes and skills underlying this competence in the classroom.

Taking these general conclusions as a starting point, some interesting aspects can be structured to allow the resulting panorama to be described more comprehensively:

the subject of History in secondary education must be vindicated as a key instrument to build democratic awareness, based on the skills of active and critical citizenship.

Students who have studied "The Maze" and "Athens" teaching units, via a participative teaching methodology have developed attitudes and abilities typical of active citizenship. To do this, it is necessary to understand history for what it is, a science, in which the historian's method (hypothetical deductive) becomes pivotal for the content. By presenting students with dilemmas about current or past relevant social problems, they become aware of the importance of participation and social commitment. The cognitive skills generated are of great interest to focus the analysis of both historical and current processes from an interpretive and reflective perspective. The contours of the analytical study of the processes that regulate the operation of the historical past have provided students with mechanisms to analyze the operation of current societies. Students do this in two ways: first, by generating their own criteria when analyzing information from different points of view; and secondly, by interpreting relevant social problems from their immediate environment. Students assume their active role in the functioning of democratic systems, underlining their right to decide and vote, which are reflected in the presentation of the results (Molina et al., 2013; Ortuño et al., 2012).

There is a relationship between the development of critical and active citizenship and the creation of learning environments that fosters reflection, analysis, interpretation and dialog.

As we have seen, the students analyzed were presented with materials based on the initial problem statement and hypothesis; the analysis of historical sources of different natures in which opposing points of view were put forward; and in the interpretation of events avoiding a presentist outlook. The teacher's role was crucial in imbuing the classroom with a suitable climate for this purpose, promoting debates, trying to lay the foundations for discussion among students and establishing agreements among them. At the same time, the teacher tried to create participatory classroom environments, where all reasoned and structured points of view of members had their place.

These spaces generated discussion and exchange of experiences and daily experiences that have allowed us to create active and motivating conceptions of the learning context designed. In this way, it has been possible to verify in the sample analyzed that the students showed motivation and interest, fundamental aspects for the improvement and achievement of the learning objectives.

In this context, it is important to take into account the different studies that comment on the subject (Prats et al., 2017; LópezFacal et al., 2017, Simpson and Dervin, 2017), which also point to the role of the teacher as a guide for the process of building democratic awareness using discovery methodologies and teaching materials such as those proposed. Learning environments that de facto foster discussion and dialog in classrooms and schools should also be established. This aspect, as we have seen, will result in a real achievement of the learning objectives set. In other words, teachers in their classrooms must emulate the functioning of a critical and active democratic society, in which the values of freedom, equality and tolerance are respected. At the same time, the inclusion of controversial issues is recommended, as is considering coeducation as a cross-disciplinary element and raising situations where awareness of the "other" becomes apparent. All these aspects have been dealt with in the two units analyzed and it has been demonstrated that they allow the cultural reference universe itself to be flexible (Sáez et al., 2017a, 2017b).

\section{Conclusions}

The interpretation of results leads us to pose an important challenge for the study of social sciences teaching methodology, for citizenship education and for schools. As has been shown, teachers form an essential part both for choosing the most appropriate content and methodologies, and for generating learning environments that foster the development of active and critical citizenship. Therefore, it is essential that teacher training should adapt to these needs. We recommend a review of the Master's in Teacher Training syllabus for future teachers of secondary education, and at the same time, insist on the importance of the Humanities in our society. 
In Couto's words (2019) "History, philosophy, languages and literature, to mention but a few, are nuclear subjects that give us direct access to knowledge of that which is fundamentally and irreducibly human" (p. 3). In addition, it is necessary to provide students with theoretical and practical instruments for the construction of curricular, methodological contents, and spaces for learning and democratic educational environments within the framework of their curricular classroom programming. The recommendation is to "democratize" classrooms in their broadest sense, seeking scenarios to build points of view on topics considered sensitive or controversial in the past and present, based on the analysis of documentation of different kinds, as well as active participation in the management processes of the proper functioning of the learning environments of the classroom and school centers.

To this end, it is essential that from research in social sciences teaching methodology, the characteristics of learning environments favorable to the development of the basic competence of active and critical citizenship are identified, this being a particularly interesting prospective study to provide continuity to this proposal. The promotion of active and critical citizenship requires training and habits, adequate learning spaces (Gardner, 1991), and learning environments (Duarte, 2003; Paniagua and Istance, 2018). This panorama of demands and challenges of the information-based society (complexity, change, uncertainty) requires a holistic, comprehensive and more functional interpretation of learning competences (DeSeCo, 2005), closely linked to the concept of practical knowledge (Shön, 1983) to understand and intervene in personal, social and professional life. This basic training context for students, in addition to learning to do, as suggested by competence teaching, allows them to learn to be, know, live and behave in the world and orient themselves. The purpose is to offer improvements both with regard to the proposed curriculum and to the organized and structured teaching activity for this purpose.

\section{Data availability}

Data sharing not applicable to this article as no datasets were generated or analyzed during the current study. All data generated or analyzed during this study are included in this article and are available from the corresponding author on reasonable request.

Received: 23 March 2020; Accepted: 24 June 2020;

Published online: 17 July 2020

\section{Notes}

1 The objective of the previous research consisted of designing, applying and evaluating resources and teaching units for the development of social competence in compulsory secondary education students in Spain through historical content (Prats et al., 2019).

2 QSRNVIVO 12 software program. Nvivo (Richards, 1999; Richards and Richards, 1991) is a program specifically designed to help organize, analyze, and find perspectives in qualitative data from interviews, open-ended survey responses, articles, social media content, and the internet. Nvivo software was created by computer scientists and social researchers on the basis of Grounded Theory Methodology (Glaser and Strauss, 1967; Strauss and Corbin, 1990, 1994) to facilitate the development of theories grounded in qualitative data. It is widely used and accepted by the scientific community at an international level (Leech and Onwuegbuzie, 2011; Zamawe, 2015; Woods et al., 2015).

3 The paragraphs are identified by the information related to each teaching unit with the following initials: A ("Athens") and M ("The Maze") and the observation session number.

4 This visualization called a cloud mark is the result of the word frequency query that Nvivo allows in this case of the "Active citizenship" node: it illustrates the terms or the words that are most often repeated in the references categorized under this node of all the records obtained and indicates-proportionally by size-their greater or lesser presence and relevance in the observations of both sets of teaching materials. The translation of the words from Spanish to English in descending order from highest to lowest is: teacher, women, question, law, answer, slaves, students, Germany.

5 The translation of the words from Spanish to English in descending order from highest to lowest is: people, poor, teacher, democracy, question, answer, citizens, slaves.

6 Cluster analysis is a visualization offered by Nvivo to illustrate the grouping or similarity of analysis categories used in this study according to the words or terms used in the references coded by each of them. The translation from Spanish to English starting with the word "Espacio", "Space" onwards are: contextualization, critical citizenship, classroom environment, student motivation, active citizenship, teaching methodology.

\section{References}

Anguera MT (1988) Observación en la Escuela. Graó, Barcelona

Antúnez S (2013) La organización escolar. Graó, Barcelona

Alves N (2002) Descifrando el pergamino: la vida cotidiana de lasescuelas en las redes lógicas. In: de Oliveira IB, Alves N (eds) Pesquisano/do cotidiano das escolas: sobre redes de saberes. DP\&A, Río de Janeiro, pp. 13-38

Armas J, López-Facal R (2012) Ciencias Sociales y educación para la ciudadanía Un diálogo necesario. Íber. Ciencias Sociales y Educación Para La Ciudadanía 71:84-91

Barca I, Schmidt MA (2013) La consciencia histórica de los jóvenes brasileños y portugueses y su relación con la creación de identidades nacionales. Educatio Siglo XXI 31(1):25-46. Available in https://revistas.um.es/educatio/article/ view/175091

Bartolomé M (1984) La pedagogía experimental. In: Sanvisens A (Dir) Introducción a la pedagogía. Barcanova, Barcelona, pp. 381-404

Benedicto J, Moran ML (2003) Aprendiendo a ser ciudadanos. INJUVE, Madrid

Bolívar A (2007) Educación para la Ciudadanía. Algo más que una asignatura, Graó, Barcelona

Bolívar A (2016) Educar democráticamente para una ciudadanía activa. Revista Internacional de Educación para la Justicia Social (RIEJS) 5:69-87. https:// doi.org/10.15366/riejs2016.5.1

Bromley P (2009) Cosmopolitanism in civic education: exploring cross-national trends, 1970-2008. Curr Issues Comp Educ 12(1):33-44. Available in https:// files.eric.ed.gov/fulltext/EJ879767.pdf

Brusa A (2010) Italia: la educación cívica, entre la utilización política y el trabajo en las escuelas. Iber. Didáctica de las Ciencias Sociales. Geografía e Historia 64:38-47

Carretero M (2007) Documentos de identidad. La construcción de la memoria histórica en un mundo global. Paidós, Buenos Aires

Carretero M, Borrell M (2008) Memoria y enseñanza de la historia en un mundo global. Problemas y desafíos. Iber. Didáctica de las Ciencias Sociales, Geografía e. Historia 55:20-29

Castañeda L (2019) Debates sobre Tecnología y Educación: Caminos contemporáneos y conversaciones pendientes. RIED: Revista Iberoamericana de Educación a Distancia 22:29-39. https://doi.org/10.5944/ried.22.1.23020

Couto RC (2019) The place of the humanities in today's knowledge society. Palgrave Commun. https://doi.org/10.1057/s41599-019-0245-6

Chaluh LN (2012) Investigar en la escuela: reflexiones teórico-metodológicas. Revista Electrónica de Investigación Educativa 14:86-105. Available in https://redie.uabc.mx/redie/article/view/298

Decree 187/2015 (2015) Diari Oficial de la Generalitat de Catalunya, Barcelona, 25 d'agost de 2015

Delgado E (2005) La formación de los ciudadanos en la enseñanza obligatoria. Una propuesta didáctica. Iber. Didáctica de las Ciencias Sociales. Geografía e Historia 44:36-44

Delgado E (2014) Educación para la ciudadanía en la enseñanza de las ciencias sociales y su vinculación con la dimensión de la memoria. Estudio de caso. Dissertation, University of Huelva (Spain). Available in http://hdl.handle.net/ $10272 / 8841$

Delgado E, Estepa J (2017) Educación ciudadana y dimensiones de la memoria en la enseñanza de las ciencias sociales: investigación sobre las concepciones del profesorado de educación secundaria en Huelva y provincia. Educación XX1 20:259-278. https://doi.org/10.5944/educXX1.19041

DeSeCo (2005) The definition and selection of key competencies. Executive summary. Availabe Via DeSeCo. https://www.deseco.ch/bfs/deseco/en/index/03/ 02.parsys.78532.downloadList.94248.DownloadFile.tmp/2005. dscexecutivesummary.sp.pdf of subordinate document. Accessed 23 Mar 2018

Duarte J (2003) Ambientes de aprendizaje: una aproximación conceptual. Estudios Pedagógicos 29:7-113. https://doi.org/10.35362/rie3312961

Edwards L, Munn P, Fogelman K (eds) (1994) Education for democratic citizenship in Europe. Swets \& Zeitlinger, Academic Pub. Division, Lisse (Netherlands)

Fuentes C, Prats J (2013) Máster de Formación del profesorado de educación secundaria: una revisión pendiente. Iber. Didáctica de las Ciencias Sociales. Geografía e Historia 75:51-57 
Fuentes C, Sabido-Codina J, Albert M (2019) El desarrollo de la competencia social y ciudadana y la utilización de metodologías activas en las aulas de secundaria. Revista Electrónica interuniversitaria de formación del profesorado 22:199-210. https://doi.org/10.6018/reifop.22.2.369671

García-Pérez F, de Alba N (2008) ¿Puede la escuela del siglo XXI educar a los ciudadanos y ciudadanas del siglo XXI?. Scripta Nova. Revista Electrónica de Geografía y Ciencias Sociales 270 (122). Available in http://www.ub.edu/ geocrit/sn/sn-270/sn-270-122.htm

Gardner H (1991) La mente no escolarizada. Paidós, Barcelona

Generalitat de Catalunya. Departament d'Ensenyament (2015) Competències bàsiques de l'àmbit social. Ciències socials: geografía i historia. Identificació $i$ desplegament a l'educació secundària obligatòria. Servei de Comunicació $i$ Publicacions, Barcelona, Available in http://ensenyament.gencat.cat/ca/ departament/publicacions/colleccions/competencies-basiques/eso/eso-socia

Glaser BG, Strauss A (1967) The discovery of grounded theory. Strategies for qualitative research. Aldine Publishing Company, Chicago. Available in http://www.sxf.uevora.pt/wpcontent/uploads/2013/03/Glaser_1967.pdf

Gibbs G (2012) El análisis de datos cualitativos en investigación cualitativa. Morata, Madrid

Gil-Jaurena I, Aguado T, Mata P, Ballesteros B (2011) Investigación sobre aprendizaje de la ciudadanía activa. Paper presented at the 5th Coloquio Internacional de Animación Sociocultural, Universidad de Zaragoza, Zaragoza (Spain), pp. 26-28 October 2011. Available at: https://scholar.google.es/ scholar?hl=ca\&as_sdt $=0 \% 2 \mathrm{C} 5 \& \mathrm{q}=$ Investigaci $\% \mathrm{C} 3 \% \mathrm{~B} 3 \mathrm{n}+$ sobre + aprendizaje + de + la + ciudadan $\%$ C3\%ADa + activa\&btnG $=$

Gil-Jaurena I (2012) Aprendizaje de la ciudadanía y la participación. Aproximación a su estudio. In: Morales S, Lirio J, Ytarte RM (coords) La Pedagogía Social en la Universidad. Investigación, formación y compromiso social, Nau llibres, Valencia, pp. 223-230.

Hauver J (2010) Democracy is a devil's snare: Theological certainly in teacher education. Theor Res Soc Educ 38(4):618-639. https://doi.org/10.1080/ 00933104.2010.10473441

Heimberg C (2010) ¿Cómo puede orientarse la educación para la ciudadanía hacia la libertad, la responsabilidad y la capacidad de discernimiento de las nuevas generaciones? Iber. Didáctica de las Ciencias Sociales, Geografía e Historia 64:48-57

Hurtado D, Gil N, Aguilar C (2019) The Maze: Gamificando el concepto de identidad. Revista Electrónica interuniversitaria de formación del profesorado 22:31-42. https://doi.org/10.6018/reifop.22.2.370351

Imbernón F (2007) La formación y desarrollo profesional del profesorado hacia una nueva cultura profesional. Graó, Barcelona

International Association for the Evaluation of Educational Achievement (2018) International Civic and Citizenship Education Study, 2016. Inter-university Consortium for Political and Social Research. pp. 10-24. https://doi.org/ 10.3886/ICPSR37147.v1

Leech NL, Onwuegbuzie AJ (2011) Beyond constant comparison qualitative data analysis: using NVivo. Sch Psychol Quart 26:70-84. https://doi.org/10.1037/ a0022711

Leenders H, Veugelers W, De kat E (2008) Teachers' view on citizenship education in Secondary education in Nederland. Cambridge J Educ 38:155-170. https:// doi.org/10.1080/03057640802063106

López-Facal R (2010) Ciudadanía. Iber. Didáctica de las Ciencias Sociales. Geografía e Historia 64:5-9

López-Facal R (2011) Aprender de los conflictos. Iber. Didáctica de las Ciencias Sociales. Geografía e Historia 69:5-7

López-Facal R, Miralles P, Prats J, Gómez-Carrasco C (2017) Enseñanza de la historia y competencias educativas. Graó, Barcelona

Mata P, Aguado T (coords) (2007) Manual Digital de Ciudadanía Global. Federación de ONG de la Comunidad de Madrid, Madrid. Available in http:// www.ciudadaniaglobal.org of subordinate document

Mata P, Ballesteros B (2011) Ciudadanía..., ¿cómo se aprende? Una investigación sobre discursos y experiencias de participación y transformación social. Revista Quaderns Digitals.Net 69. Actas del Congreso Mejora Educativa y Ciudadanía Crítica. Available in http://www.quadernsdigitals. net/index.php?accionMenu=hemeroteca.VisualizaArticuloIU.visualiza\& articulo $\mathrm{id}=11050 \&$ PHPSESSID $=2 \mathrm{~d} 79999838 \mathrm{a} 38$ f990f8a4d470cc88189

Mata P, Ballesteros B, Padilla MT (2012) Ciudadanía crítica, participativa y transformadora: experiencias de aprendizaje. In: Nicolás A, García-Pérez F, Santisteban A (coords) Educar para la participación ciudadana en la enseñanza de las Ciencias Sociales, vol 2. Asociación Universitaria de Profesores de Didáctica de las Ciencias Sociales y Diada Editora, Sevilla, pp. 131-138

Mattozi I (2008) Memoria y formación histórica. La memoria en la clase de Historia. Iber. Didáctica de las Ciencias Sociales, Geografía e Historia 55:30-42

Maykut P, Morehouse R (1999) Investigación cualitativa: una guía práctica y filosófica. Hurtado, Barcelona

Mejía W (2009) What criticisms are made to the content of history science textbooks? Paper presented at the International Seminar History and Social Science Textbook. Ministerio de Educación de Santiago de Chile, Santiago de Chile, pp. 11-12 (November)
Molina S, Miralles P, Ortuño J (2013) Concepciones de los futuros maestros de Educación Primaria sobre formación cívica y ciudadana. Educatio Siglo XXI 31(1):105-126. https://revistas.um.es/educatio/article/view/175361/148441

Molina J (2016) La Educación para la ciudadanía democrática en las aulas de Educación Secundaria Obligatoria: configuración de las ideas y actitudes sociopolíticas del alumnado en Catalunya. Dissertation, University of Barcelona

Myers J (2006) Rethinking the social studies curriculum in the context of globalization: education for global citizenship in the U.S. Theor Res Soc Educ 34 (3):370-394. https://doi.org/10.1080/00933104.2006.10473313

Oliveira IB, Alves N (2002) Contar el pasado, analizar el presente y soñar el futuro. In: Oliveria IB, Alves $\mathrm{N}$ (eds) Pesquisa no/do cotidiano das escolas: sobre redes de saberes. DP\&A, Río de Janeiro, pp. 7-122

Ortuño J, Gomez-Carrasco C, Ortiz E (2012) La evaluación de la competncia educativa social y ciudadana desde la didáctica de las ciencias sociales. Un estado de la cuestión. Didáctica de las Ciencias Experimentales y Sociales 26:53-72. Available in https://ojs.uv.es/index.php/dces/article/view/1931/ 1444

Pagès J, Oller M (2005) Las representaciones sociales del derecho, la justicia y la ley de un grupo de adolescentes catalanes de $4^{\circ}$ de ESO. Enseñanza de las Ciencias Sociales 6:3-19. Available in https://www.raco.cat/index.php/ EnsenanzaCS/article/view/126325

Pagès J, Santisteban A (2010) La educación para la ciudadanía en la Enseñanza de las Ciencias Sociales, la Geografía y la Historia. Iber. Didáctica de las Ciencias Sociales, Geografía e Historia 64:8-16

Paniagua A, Istance D (2018) Teachers as designers of learning environments: the importance of innovative pedagogies. OECD Publishing, Paris

Parker WC (2003) Teaching democracy: unity and diversity in public life. Teachers College Press, New York, NY

Pinto H (2013) Usos del patrimonio en la didáctica de la historia: perspectivas de alumnos y profesores portugueses relativas a identidad y conciencia histórica. Educatio Siglo XXI 31(1):61-88. Available in https://revistas.um.es/educatio/ article/view/175341

Prats J, Santacana J (2011) Enseñar a pensar históricamente: la clase como simulación de la investigación. In: Prats J (ed) Didáctica de la Geografía e Historia. Ministerio de Educació, Graó, Barcelona, pp. 7-122

Prats J, Molina J, Ruiz A, Molina-Luque F (2017) Análisis de las representaciones e ideas del alumnado en educación para la ciudadanía democrática: ejemplo de mixed methodology desde y para la investigación transdisciplinar. RISE: Int Jo Sociol Educ 6:1-25. https://doi.org/10.17583/rise.2017.2479

Prats J, Fuentes C, Sabariego M (2019) La investigación evaluativa de materiales didácticos para la educación política y ciudadana a través de contenidos históricos. Revista electrónica interuniversitaria de formación de profesorado 22:1-15. https://doi.org/10.6018/reifop.22.2.370051

Ramos FJ (2016) Educación y ciudadanía: la necesidad de generar espacios para la discrepancia y el diálogo. Foro de Educación 14(20):13-19. https://doi.org/ 10.14516/fde.2016.014.020.002

Royal Decree 1105/2014 (2015) Boletín Oficial del Estado. 3 de enero de, Madrid Rey B, Staszweski M (2004) Enseigner l'historie aux adolescents. Demarche socioconstructivistas. De Boeck, Bruxelles

Richards L (1999) Using NVivo in qualitative research. SAGE Publications, London

Richards T, Richards L (1991) The NUDIST qualitative data analysis system. Qualit Sociol 14(4):307-324. https://doi.org/10.1007/BF00989643

Sabariego M (2010) Etnografía y estudio de casos. In: Nieto S (ed.) Principios, métodos y técnicas para la investigación educativa. Dykinson, Madrid, pp. $425-445$

Sánchez-Melero H, Gil-Jaurena I, Aguado MT (2016) Aprendizaje de la ciudadanía desde los espacios y prácticas ciudadanas. Estudio de caso en curso. Paper presented at XVI Congreso Nacional y VII Congreso Iberoamericano de Pedagogía: Democracia y Educación en el siglo XXI, Universidad Complutense de Madrid, pp. 28-30 June 2016. Available in https://biblioteca.ucm.es/ data/cont/docs/405-2016-10-05-LibroDeActas SEP2016.pdf

Santacana J, Martínez (2013) Patrimonio, identidad y educación. Una reflexión teórica desde la historia. Educatio Siglo XXI 31(1):47-60. Available in https:// revistas.um.es/educatio/article/view/175331

Sáez I, Bellatti I, Mayoral P (2017a) La formación ciudadana en la Educación secundaria obligatoria en Catalunya. Análisis del concepto de ciudadanía en el curriculum. RISE: Int J Sociol Educ 6:110-131. https:/doi.org/10.17583/ rise.2017.2471

Sáez I, Molina J, Barriga E (2017b) La enseñanza y aprendizaje de las ciencias sociales y el desarrollo de la competencia social y ciudadana. In: López-Facal R, Miralles P, Prats J (eds) Enseñanza de la historia y competencias educativas. Graó, Barcelona, pp. 105-118

Sánchez-Agustí M (2011) Ciudadanía y enseñanza de la Historia. Resultados de una intervención en la formación de maestros. Didáctica de las Ciencias Experimentales y Sociales 25:3-15. https://dialnet.unirioja.es/servlet/articulo? codigo $=3765383$ 
Seixas P, Grosselin V, Ercikan K (2010) Cuestionar el pasado. Los canadienses antes las polémicas historiográficas. Iber. Didáctica de las Ciencias Sociales. Geografía e Historia 64:58-67

Shön D (1983) The reflective practitioner. How professionals think in action. Basic Books, New York, NY

Schulz W, Ainley J, Cox C, Friedman T (2018) Young People's views of government, peaceful coexistence, and diversity in five Latin American countries: IEA International Civic and Citizenship Education Study 2016 Latin American Report. IEA, Amsterdam

Simpson A, Dervin F (2017) 'Democracy' in education: an omnipresent yet distanced 'other'. Palgrave Commun. https://doi.org/10.1057/s41599-017-0012-5

Spradley J (1980) Participant observation. The George Washington Unviersity Institute for Ethnographic Research, Washington

Strauss A, Corbin J (1990) Basics of qualitative research. SAGE Publications, London

Strauss A, Corbin J (1994) Grounded Theory Methodology, an overview. In: Denzin NK, Lincoln YS (eds) Handbook of qualitative research. SAGE Publications, New York, NY

Trafford B (2008) Democratic schools: Towards a definition. In: Arthur J, Davies I, Hahn C (eds) The SAGE handbook of education for citizenship and democracy. Sage, London, pp. 527

Travers RMW (1971) Introducción a la investigación educacional. Paidós, Buenos Aires

Tutiaux-Guillon N (2003) L'Histoire enseignée entre coutume disciplinaire et la formation de la conscience historique. In: Tutiaux-Guillon N (ed) Identités, mémoires, consciente historique. Université de Saint Etienne, Saint Etienne

Tutiaux-Guillon N (2009) Los IUFM y el nuevo máster. Iber. Didáctica de las Ciencias Sociales. Geografía e Historia 61:48-56

Valls R (2009) Ciudadanía y multiculturalidad en la enseñanza de las ciencias sociales: el desajuste entre intenciones educativas y prácticas escolares. In: Ávila R, Borghi B, Mattozzi I (eds) L'Educazione alla cittadinanza europea e la formazione degli insegnanti. Patron Editore, Bologna, pp. 109-116. coords

Van Dalen DB, Meyer WJ (1980) Manual de técnica de investigación educacional. Paidós, Buenos Aires

Walzer M (1997) Las esferas de la justicia. Una defensa del pluralismo y la igualdad. Fondo de Cultura Económica, México

Wood PH, Smith J (2018) Investigar en educación. Conceptos básicos y metodología para desarrollar proyectos de investigación. Narcea, Madrid

Woods M, Paulus T, Atkins DP, Macklin R (2015) Advancing qualitative research using qualitative data analysis software (QDAS)? Reviewing potential versus practice in published studies using ATLAS.ti and NVivo, 1994-2013. Social Science Computer Review. https://doi.org/10.1177/0894439315596311

Yeager E, Humphries EK (2012) A Social Studies teacher's sense making of controversial issues discussions of race in a predominantly white, rural high school classroom. Theor Res Soc Educ 39(1):92-114. https://doi.org/10.1080/ 00933104.2011.10473448
Zamawe FC (2015) The implication of using NVivo software in qualitative data analysis: Evidence-based reflections. Malawi Med J 27(1):13-15. https://doi. org/10.4314/mmj.v27i1.4

\section{Acknowledgements}

We would like to thank the research group Teaching Methodology of History, Geography and other Social Sciences (Spanish DHIGECS) for their contribution to the main research entitled: "Development of sociopolitical training for democratic citizenship: design and implementation of teaching materials in the Social Sciences (R\&D EDU 201565621-C3-3-R)", the source of some of the data in this article. We also thank the group's researchers for collecting some of the data analyzed. We are grateful to Joaquín Prats, principle investigator of DHIGECS, for his feedback. We would also like to thank Sean Murphy for his translation from Spanish to English.

\section{Competing interests}

The authors declare no competing interests.

\section{Additional information}

Correspondence and requests for materials should be addressed to C.F.-M.

Reprints and permission information is available at http://www.nature.com/reprints

Publisher's note Springer Nature remains neutral with regard to jurisdictional claims in published maps and institutional affiliations.

\begin{abstract}
cc) (i) Open Access This article is licensed under a Creative Commons Attribution 4.0 International License, which permits use, sharing, adaptation, distribution and reproduction in any medium or format, as long as you give appropriate credit to the original author(s) and the source, provide a link to the Creative Commons license, and indicate if changes were made. The images or other third party material in this article are included in the article's Creative Commons license, unless indicated otherwise in a credit line to the material. If material is not included in the article's Creative Commons license and your intended use is not permitted by statutory regulation or exceeds the permitted use, you will need to obtain permission directly from the copyright holder. To view a copy of this license, visit http://creativecommons.org/ licenses/by/4.0/.
\end{abstract}

(C) The Author(s) 2020 